\title{
FREE TRADE AND DEMOCRATIZATION: THE OMINOUS LINK IN THE GASE OF EGYPT
}

\author{
Arş. Gör. Dr. Ertuğrul Cevheri \\ Adana Bilim ve Teknoloji Üniversitesi \\ Siyasal Bilgiler Fakültesi \\ ORCID: 0000-0001-5579-4811
}

\begin{abstract}
This article shall examine the frequently studied relationship between free trade and democratization by taking Egypt as the case study. Egypt has gradually removed barriers against free trade over the years but unlike the claims of some studies in the literature, economic development stemming from free trade policies did not transform Egypt into a country with a more pluralist political system. The reason that trade liberalization has not been instrumental in Egypt's democratization is related with the fact that Egypt's trade liberalization policies were designed, negotiated and implemented by a small group of politicians who happened to have close ties with the business world and in some cases, they directly hailed from the business world. Naturally, these policies merely reflect narrow crony capitalist interests, at the expense of other social classes, particularly the middle class. Thus, as far as the Egyptian example is concerned, the relationship between free trade and democratization could be labelled as ominous since middle classes are generally regarded as instrumental in the formation a democratic system and trade liberalization or neoliberal economic policies in general have been pursued to the detriment of middle class Egyptians.
\end{abstract}

Keywords: Free trade, Democratization, Egypt, Middle classes, Mubarak regime

Serbest Ticaret ve Demokratikleşme: Misır Örneğindeki Meşum Bağlantı

\section{Öz}

Bu makale, sıklıkla çalışılan bir konu olan serbest ticaret ve demokrasi arasındaki ilişkiyi Mısır örneği üzerinden inceleyecektir. Mısır kademeli bir şekilde serbest ticaretin önündeki engelleri kaldırmasına rağmen, literatürde bazı çalışmaların iddia ettiğinin aksine, serbest ticaret politikalarından kaynaklanan ekonomik gelişme Mısır'da daha çoğulcu bir politik sistemin ortaya çıkmasına yol açmamıştır. Serbest ticaret politikalarının Mısır'ın demokratikleşmesinde rol oynamamasının sebebi, söz konusu politikaların, iş dünyasına yakın ve hatta bazı durumlarda doğrudan iş dünyasından çıkmış küçük bir grup politikacı tarafından dizayn edilmesi, müzakere edilmesi ve uygulanmasıdır. Doğal olarak söz konusu bu politikalar, diğer sosyal sınıfların, özellikle de orta sınıfın çıkarlarını bir tarafa bırakarak daha çok ahbap çavuş kapitalizminin dar çıkarlarını yansıtmaktadır. Dolayısıyla, Mısır örneği özelinde, serbest ticaret ve demokratikleşme arasındaki ilişkiyi meşum olarak nitelendirmemiz mümkündür çünkü genel olarak orta sınıfların demokrasinin ortaya çımasında önemli rol oynadıkları ifade edilmektedir ve serbest ticaret de dahil neoliberal ekonomi politikalarının orta sınıfa mensup Mısırlıların aleyhine olacak bir şekilde takip edildiğini öne sürmemiz mümkündür.

Anahtar Sözcükler: Serbest ticaret, Demokratikleşme, Mısır, Orta sınıflar, Mübarek rejimi

* Makale geliş tarihi: 08.01.2019

Makale kabul tarihi: 22.03.2019

Erken görünüm tarihi: 12.04.2019 


\section{Free Trade and Democratization: The Ominous Link in the Case of Egypt}

\section{Introduction}

Prominent democracy promotion actors such as the European Union (EU) or the United States (US) have established a bond between economic development and democratization, thus for those actors, nourishing the economic development of target countries is a means to achieve democratization. These actors, particularly the EU, opt for the neoliberal model of economic development (Cevheri, 2018: 142; Reynaert, 2011: 627-628) which comes at the expense of other models of economic development such as the "shared-growth" (King, 2003: 17-18) model.

Removing all barriers - whether they be tariff based or not - in front of global trade, or simply free trade is one of the most important tenets of the neoliberal model of economic development. The EU's inclination towards the neoliberal model has translated well into the actual policy that the EU conducts. The association agreements that the EU signs with its Southern Mediterranean partners entail articles about the abolishment of trade barriers between EU member countries and the respective Southern Mediterranean partner. As of 2018, a single free trade area (Euro-Mediterranean Free Trade Area, EMFTA) between the EU and the entire Southern Mediterranean region has yet to be achieved, thus the EU concludes association agreements with each partner - bar Libya and Syria - separately.

Promoting or consolidating democracy through promoting free trade has been a go-to method for actors of democracy promotion. There is an ample amount of studies that supports this kind of an approach. In a nutshell, many studies - which are to be explored in greater detail in the next section - assert that there is an inherent connection between free trade and democratization since free trade is conducive to economic development and economic development in return fosters democratization.

Free trade policies in the South Mediterranean predate democracy promotion campaigns by the EU and the US as they took off only after the conclusion of the Cold War. Nevertheless, both the US and particularly the EU have been very instrumental in assisting their southern partners with the removal 
of trade barriers. The cooperation agreements signed with every Southern Mediterranean country - with the exception of Libya - starting with Israel in 1975, foresaw the establishment of free trade areas with each country.

As with other countries, Egypt also signed a cooperation agreement with the European Communities (EC) - the legal predecessor of the EU - in 1977. This agreement set out the terms of free trade between Egypt and the EC in accordance with the rules and principles of the General Agreement on Tariffs and Trade (GATT) (Mishrif, 2010: 73). Since then, Egypt has further liberalized its trade with the EU. Even though some protectionist measures still prevail in the trade of agricultural products, the volume of trade between Egypt and the EU has been on the rise ever since the 2004 Association Agreement entered into force (European Commission, 2018a). Moreover, Egypt and the EU are currently in talks to deepen their mutual trade even further by signing a Deep and Comprehensive Free Trade Agreement (DCFTA).

Trade liberalization in Egypt, which has gained momentum in the $21^{\text {st }}$ Century has not led to substantial democratization in Egypt. Some reforms have been put forward such as the introduction of multi-candidate presidential elections, nevertheless these reforms were mostly cosmetic and shallow, bereft of any meaningful of change. The 2005 presidential elections and the whole Ayman Nour drama $^{1}$ is a stark proof of this, along with the 2010 parliamentary elections. Instead of a period of gradual democratization, political pluralism in Egypt has actually declined, as pointed out by Jason Brownlee (2003).

This came against a background of economic development as far as development measured in terms of gross domestic product is concerned. For instance, in the year 2008, partially thanks to the neoliberal economic prescription, which also involved trade liberalization, Egypt achieved an "unprecedented" growth rate of 7\% (Daily News Egypt, 2008). This growth rate was achieved amidst an environment of turmoil that was reminiscent of the 'bread riots' of 1977, as many citizens revolted to protest rising bread prices caused by the Egyptian government's decision to cut subsidies.

1 Ayman Nour, an Egyptian lawyer and politician, who has been living in a selfimposed exile in Turkey ever since the Egyptian coup d'état in 2013, decided to challenge Hosni Mubarak for the 2005 presidential elections, the country's first multicandidate presidential elections. As the leader of the liberal El-Ghad Party, Nour was first arrested in early 2005 and he was charged with forging signatures required for his candidacy. Following domestic and international uproar, Nour was released from the prison and he was allowed to contend Mubarak in the elections. However, after the elections in which he suffered a heavy defeat against Mubarak, Nour was once again arrested and he remained in prison until 2009 when he was discharged from prison on health grounds. 
Free trade policies, along with other neoliberal economic policies, has led to a growth in the Egyptian economy, but this economic development in return has not fostered democratization in Egypt, which goes against the claims of many studies in democratization literature. The main reason for this is the way in which free trade policies - that are accompanied by other neoliberal economic policies such as privatization - tamper with the dynamics of a society, particularly to the detriment of middle classes, which are usually seen as the driving force behind democratization. Moreover, measures towards freer trade in Egypt has mostly been negotiated and advanced by a group of economic and political elites that either belong to or can be associated with the authoritarian regime of Hosni Mubarak. Carlos Heredia (1994: 19-20) reports a similar situation in Mexico, in which negotiations for the North American Free Trade Agreement (NAFTA) were mostly conducted by a group that consists of "top levels of government and business" while at the same time the alleged benefits of the NAFTA for the rest of the Mexicans would be slow to materialize, to say the least.

The remainder of the article will comprise of three sections and a conclusion. First, the relationship between free trade and democratization shall be uncovered by making specific references to economic development and modernization. Second, Egypt's progressive elimination of impediments in front of foreign trade is going to be elaborated in three subsections. Last, but not least, the relationship between neoliberal economic policies including trade liberalization, modernization and democratization in Egypt will be analysed by incorporating an array of Egyptian political actors including Islamists, military elites and perhaps most importantly a group of capitalist civilian elites that came into the spotlight in the last decade of Mubarak's rule. The article shall conclude by reaffirming the perilous effects of free trade policies - and neoliberal economic policies in general - on Egypt's already precarious democratization.

\section{The Linkage Between Free Trade and Democratization}

There is a vast body of literature that scrutinizes the relationship between free trade and democratization. Whereas some studies such as (Lopez-Cordova and Meissner, 2008; Milner and Kubota, 2003; Acemoğlu and Robinson, 2006; Liu and Ornelas; 2014) empirically assert that trade liberalization is conducive to democratization, others such as ( $\mathrm{Li}$ and Reuveny, 2003; Grossman, 2002; Rigobon and Rodrik, 2005), find a negative link between free trade and democratization. Many politicians have also joined the discussion about free trade and democratization. For instance, former US presidents Bill Clinton and George W. Bush both stressed the importance of free trade for its role in the liberalization of political systems (Clinton, 1996: 36; Marquis, 2001). Like his 
American counterparts, former Mexican president Carlos Salinas de Gortari also emphasized the role of free trade policies. Salinas, backed by the "Mexican industrial and banking oligarchies" pledged to support "economic reform, trade liberalization and democratization" by integrating Mexico into the American economy (Rosen, 2002: 161).

So, how does the relationship between free trade and democratization work? At the risk of oversimplification, Ernesto Lopez-Cordova and Christopher Meissner (2008: 543) formulate the relationship between free trade and democratization as a two-step process. According to them, globalization ${ }^{2}$ leads to economic development and this in return leads to democratization. As stated by Lopez-Cordova and Meissner, the second step of this process, which can be associated with the works of American social scientist Seymour Martin Lipset, is generally known as the 'modernization theory' (ibid.: 544).

Before we delve into the details of the modernization theory, it is best to probe the first step of the relationship, namely the relationship between free trade and economic development. As reported by Francisco Alcala and Antonio Ciccone, international trade's effect on productivity is "statistically and economically significant as well as robust" (Alcala and Ciccone, 2004: 638). Nevertheless, we cannot with certainty assert that free trade leads to more productivity and development at all times, as Randall Schweller (2000: 53) succinctly puts it, there are winners and losers of free trade. In addition to Schweller, other authors are either sceptical about the positive relationship between trade openness and growth (Rodriguez and Rodrik, 2001:266) or they provide evidence in contrast to it (Carlsson and Lundström, 2002: 342).

Even if we accept the relationship between free trade and economic development as positive, as in the case of Egypt, we still cannot claim that economic development necessarily brings democratization, which leads us to the second part of the two-step relationship between free trade and democratization. The so-called modernization theory, as put forward by Lipset, basically argue that a country's prospects of becoming more democratic increases as that country goes through a period of modernization stemming from economic development. In Lipset's (1959: 75) own words "the more well-to-do a nation, the greater the chances that it will sustain democracy". According to Lipset, there is a correlation

2 Even though Lopez-Cordova and Meissner do not directly use the phrases 'free trade' or 'trade liberalization' we can still safely assume that by using the word 'globalization' they refer to free trade since free trade is an important component of globalization. 
between economic development - defined in terms of wealth ${ }^{3}$, industrialization, urbanization and education - and democratization (ibid.). Other scholars such as Harvard based economist Robert Barro (1999: 160; 2015: 935) also point out to statistical evidence between modernization and democratization.

Lipset's analysis is problematic from two different perspectives. First, higher GDP per capita does not necessarily mean higher income equality. Countries with similar GDP per capita may have drastically different structures in terms of income equality, for instance, Romania and Russia have similar GDP per capita - Romania \$10813 and Russia \$10743 (World Bank, 2017) - yet these countries differ greatly as far as income equality is concerned. While Romania's Gini index is only 27.3 - lower Gini index means higher income equality Russia's Gini index is much higher, standing at 41.2, placing Russia above Romania significantly concerning income inequality (CIA, 2017). Where wealth is concentrated in hands of few oligarchs, as in the case of Russia, an increase in GDP and accordingly GDP per capita does not necessarily bolster democratization. Russia has achieved positive GDP per capita growth rates ever since Vladimir Putin came into power in 2000, with the exception of 2009 - in which the main culprit was the global economic crisis of 2008 - and the period between 2014 and 2016 (World Bank, 2017). Nevertheless, Russia's increasing GDP per capita has never been trailed by a process of democratization. In fact, political rights and civil liberties in Russia has deteriorated, as shown by the oftcited democracy index Freedom House ${ }^{4}$ (Freedom House, 2018).

Second, some of the indices used by Lipset to define wealth and accordingly development, may not always necessarily contribute to democratization. For instance, Lipset asserts that the number of radios per thousand persons is an indicator of wealth and this in return is one of the components of economic development (Lipset, 1959: 75). In Lipsetian explanation, economic development is crucial in the sense that states modernize following economic development. However, modernization along the lines of number of radios - or any other indicator used by Lipset such as the number of physicians per person (ibid.) - may fail to account for democratization under certain circumstances. An increase in the number of radios per person does not

3 Lipset states that 4 different indices of wealth are the following: per capita income, number of persons per motor vehicle, number of persons per physicians and the number of radios, telephones and newspapers per thousand persons (Lipset, 1959: 75).

4 Whereas Russia was classified as a 'partly free' country in 2001, as of 2018, Russia is listed as 'not free'. While the Freedom House categorizes countries in accordance with the 'freedom' that they have, it is still safe to assume that 'free' countries are democratic while on the other hand countries that have the status of 'not free' are authoritarian. 
mean much for democratization if most of the radio stations in that country is directly or indirectly controlled by the authoritarian regime. The same thing goes for number of physicians per person, in many authoritarian regimes, and even in ones that could be defined as totalitarian such as Belarus and North Korea, number of doctors have risen steadily (Nation Master), yet no democratization has followed the suit. Having better standards of health service does not automatically mean better prospects of democratization. Even if we do not nitpick Lipset's conception of modernization and instead assume modernization as a whole concept, it is still dubious to claim that modernization leads to democratization at all times, as illustrated in the literature as well (Collier, 1979: 19-20; O’Donnell, 1973: 3-15, 113-114).

To sum up, modernization theory, with its claim that modernization is the panacea that is needed for democratization, fails to offer a uniform account for the moves towards more democratic forms of government. This is particularly the case for the Middle East, the modernization theory is at pains to explain the Middle Eastern countries' failure to move towards democracy (Waterbury, 1994: 32-33).

What seems to be the problem is that economic development as a means to democratization does not always operate under all circumstances. The road towards economic development is as important as economic development itself. Years of economic development generated by following neoliberal economic policies including trade liberalization came at the sacrifice of lower classes and particularly middle classes, and instead regime elites prospered even further. This is hardly surprising, given that free trade policies - or neoliberal economic policies in general - is usually implemented by a small group of regime elites. This has been exactly the case in Egypt, especially during the Mubarak era, the National Democratic Party's (NDP) Policies Committee, which was mainly responsible for Egypt's restructuring along neoliberal lines, was being led by Hosni Mubarak's son Gamal and a few crony capitalists including steel magnate Ahmed Ezz.

\section{Trade Liberalization in Egypt}

In this section, the steps that Egypt has taken in order to liberalize its foreign trade shall be examined in three subsections. The first section will focus on the trade relations between Egypt and the EU, arguably the most advanced trade relations that Egypt has ever achieved with a third party. The second section will be about US-Egypt trade relations. Egypt's trade with the US, while as not as advanced as the EU-Egypt trade relations, still progressed to a certain extent ever since Egypt concluded a separate peace treaty with Israel. This is not really surprising since, given the proximity, the EU has historically been the main 
trading partner of Egypt while the US is the main partner in military and strategic affairs. The final section will cover Egypt's trade relations with the rest of the world, particularly trade liberalization within the Middle East.

\subsection{EU-Egypt Trade Relations}

Trade liberalization with the EU goes back to the 1972, the year in which Egypt signed an agreement with the EC, in order to secure most favoured nation status (Gad, 2003: 186). Nevertheless, this arrangement was replaced by a cooperation agreement five years later. This 1977 agreement was rather limited in scope though, especially if we compare it to the 2004 Association Agreement as the former agreement did not entail any clauses for cooperation in political, social and cultural affairs. Furthermore, according to the 1977 agreement, the aid, or financial protocols to be more specific, that the EC granted to Egypt were not subject to any conditionality.

Strictly speaking, the 1977 cooperation agreement was confined to cooperation in financial and trade related affairs. This agreement provided Egyptian manufactured goods "non-reciprocal access" to the European markets while agricultural products did not receive the same treatment (United Nations, 2003: 16). This was rather problematic for Egypt because agriculture was arguably one of the sectors in which Egypt could have had the upper hand over the EC. In order to redress this situation, the cooperation agreement was amended by an additional protocol in 1987 that partially liberalized trade in agricultural products (European Commission, 2018b).

The year 2004 marks a milestone in EU-Egypt trade relations. According to the European Commission, following the signature of the association agreement, the volume of trade between Egypt and the EU has more than doubled and in 2007, it stood at $€ 27.9$ billion (European Commission, 2018a). In addition to the association agreement, a second agreement on "agricultural, processed agricultural and fisheries products" was signed in 2009 that entered into force in 2010 (ibid.). Full liberalization in agricultural products, however, will likely to remain unachievable, due to protectionism under the umbrella of the EU's Common Agricultural Policy (CAP).

\subsection{US-Egypt Trade Relations}

While the relations between the US and Egypt ebbed and flowed during the Nasser era, partially due to Nasser's positive neutralism; under the rule of Anwar Sadat, Egypt was fully incorporated into the Western bloc. Egypt's separate peace treaty with Israel in 1979, which led the Arab League to suspend Egypt's membership, and the Egypt's move towards dismantling the remnants of 
Soviet presence within the country made Egypt a valuable ally for the US. The US in return, generously supported the Sadat regime and it continued to do so after Mubarak replaced Sadat, following the latter's assassination. Egypt was and still is the second largest recipient of US military aid behind Israel (Tamkin, 2017). Jason Brownlee estimated that during the period between 1979 and the Arab Spring, the US government had spent more than $\$ 60$ billion in order to keep the Mubarak regime afloat (Brownlee, 2012).

While the US and Egypt are close allies, they are not really close trading partners. As of this writing, no free trade agreement is in force between the US and Egypt even though the negotiations are still in progress. The negotiations for the free trade agreement lagged behind mainly because of issues related with intellectual property (Sharp, 2011: 23) an area in which Egypt ranks low, even within the Arab world (Hassanein, 2017). The negotiations also temporarily halted in 2006 due to the conviction of opposition politician Ayman Nour (Dunne, 2007: 7).

Despite the lack of a free trade agreement, in 2017, the volume of trade between two parties still stood at $\$ 5.6$ billion, making the US Egypt's third largest trading partner (Export.gov). Egypt still benefits from other trading arrangements including a Qualifying Industrial Zone (QIZ) and a Generalized System of Preferences (GSP). While the QIZ unilaterally allows the Egyptian companies to transfer their goods produced in specially designated zones - the goods must have certain Israeli component in them - without any tariffs, the GSP confers duty-free access for certain products (American Chamber of Commerce in Egypt, 2018). Moreover, there are two treaties in force between Egypt and the US that regulate trade, a Bilateral Investment Treaty (BIT) that was signed in 1986 and a Trade and Investment Framework Agreement (TIFA) that was signed in 1999.

\subsection{Egypt-Rest of the World Trade Relations}

Egypt has progressively removed hurdles in front of free trade within the Arab World. In 1997, Egypt, along with 13 other Arab countries established the Greater Arab Free Trade Area (GAFTA). While the GAFTA does not cover free trade in services, it could still be considered as an ambitious project as it aimed to achieve customs union by 2015 and common market by 2020 even though it has already missed its first target. In addition to the GAFTA, Egypt also participates within the framework of the Agadir Agreement that was signed in 2004 with 3 other Arab countries: Jordan, Morocco and Tunisia. It was hoped that the agreement would be the initial step towards the establishment of a larger free trade area, the EMFTA, with participants from both sides of the Mediterranean. The EMFTA failed to materialize nonetheless, mostly due to the 
Arab-Israeli conflict. As stated by Ferdi de Ville and Vicky Reynaert (2010: 206), a free trade area in the Middle East in which Israel participates as a full member remains an illusion as long as the Arab-Israeli conflict remains unresolved.

Egpyt also participates in trade liberalization efforts within Africa. Egypt was one of the founding members of the Common Market for Eastern and Southern Africa (COMESA). Moreover, Egypt, along with 43 other African countries signed the African Continental Free Trade Agreement (AfCFTA). Should the agreement enter into force following ratification, it will have established one of the largest free trade areas in the world.

\section{Free Trade and Democratization in Egypt: The Ominous Link}

The process of modernization in Egypt, starting with the coup ${ }^{5}$, staged by the so-called Free Officers against the Egyptian monarchy under the rule of King Farouk I, intensified with Anwar Sadat coming into power and adopting a neoliberal model of development (the Infitah or the Open Door policy). Ever since then, Egypt has improved markedly in many facets of modernization, perhaps most importantly in GDP per capita over the years following Gamal Abdel Nasser's death. There was 16-fold increase in Egypt's GDP per capita during the period between 1970-2015 (World Bank, 2017). Egypt's GDP per capita skyrocketed after 2004 (ibid.), the year in which neoliberal reforms including trade liberalization have picked up pace under the government of Ahmed Nazif. 2004 was also the year that the association agreement between Egypt and the EU entered into force. Naturally, as has been mentioned before, the volume of trade between Egypt and the EU has increased significantly following 2004.

Egypt's quest towards modernization has not transformed Egypt into a Western-style pluralist democracy as many expected. In fact, Egypt went through a transformation, but Egypt's transformation did not make Egypt a more democratic polity. Under the leadership of Sadat, Egypt transformed from single mass party politics to façade multi-partyism and this arrangement was mostly perpetuated during Hosni Mubarak's 30 years tenure. Unlike the period of Gamal Abdel Nasser, in which legitimacy was derived through populist policies, the presidency of Sadat was marked by a transformation into a post-populist

5 Actually, Egypt's modernization could be traced back to the times of Muhammad Ali Pasha. However, monarchy era Egypt could still be characterized by feudalism to a certain extent. In fact, Gamal Abdel Nasser himself lamented that for many years, the Egyptians had been looking for "a policy capable of eradicating the evils accumulated by feudalism" (Nasser, 1955). 
authoritarian state (Hinnebusch, 1988) in which legitimacy was sought by imposition from above. Mubarak maintained and, in some ways, enhanced the legacy of post-populist authoritarianism in Egypt. Post-populist authoritarianism, which could be characterized by "liberalization without democratization" (Hinnebusch, 2000) is still going in full force in Egypt, under the presidency of Abdel Fattah el-Sisi. As has been stated before, Egypt currently negotiates a DCFTA with the EU in order to achieve further trade openness. Egypt's advanced trade liberalization, along with other neoliberal policies, has not made Egypt a more democratic place and actually, democratic freedoms have further retreated recently, as can be seen from the state of civil society (Chick, 2017; Mikhail 2014; Herrold and Atia, 2016: 404-405) and political parties (Reuters, 2014).

The problem with modernization, or to be more specific, the inability of Egyptian modernization to trigger democratization is not necessarily a problem with modernization per se. Instead, the way that that modernization is being sought plays a critical role in the presence of democracy - or lack thereof - in Egypt. With the exception of Nasser period, Egypt hitherto pursued modernization by adopting a mode of development that could be characterized by neoliberalism. Significant growth rates aside, - which did not really trickle down to lower strata of Egyptian society - structural adjustment in Egypt has had catastrophic effects on Egyptians from many walks of life, and this in return has important consequences for democratization in Egypt.

As was mentioned in the introduction, bread riots of both 1977 and 2008 were the perfect embodiment of discontent towards neoliberalism in Egypt. In both incidents, the main culprit was the reduction of subsidies in bread, arguably the staple food of Egyptian people. Egyptian people's dissatisfaction with the implementation of structural adjustment programs has revealed itself in many instances. For example, number of strikes in Egypt more than doubled in 2004, in comparison to the period between 1998 and 2003. The strikes were a response to the Nazif government's wide-ranging neoliberal reforms, perhaps most importantly privatization (Beinin, 2012: 326-327). The largest - if not the largest - of the strikes took place in 2006 in the city of El Mahalla El Kubra, in a company called Misr Spinning and Weaving. The underlying reason behind textile workers' disgruntlement was the rising inflation mainly due to prices left to be determined mostly by the market. Concomitant to this development was a sharp deterioration in the textile workers' living standards (Beinin, 2007).

Egyptian people's resentment towards declining living standards reached its peak on the eve of Arab Spring. In his article, Hazem Kandil painted a bleak picture of the state the Egyptians were in right before the Egyptian chapter of the Arab Spring, As stated by Kandil, Egypt's per capita income dropped 7 percent between the period 2000-2006. Moreover, almost half of the Egyptians (47 
percent) were making less than $\$ 2$ a day (Kandil, 2012: 210). This predicament of many Egyptians stood in stark contrast to few privileged Egyptians' experiences, who enjoyed luxuries such as high-end shopping centers, gated communities and private jets (Cook, 2013: 175). Thus, it should not come as a surprise that authors such as Marc Lynch defined Arab Spring as a "direct rejection of neoliberalism" (Lynch, 2011).

\subsection{Egyptian Islamists, Neoliberalism and Free Trade}

Egyptian state's gradual withdrawal from service providing, in accordance with neoliberal restructuring, gave Egyptian Islamists ample amount of opportunities to build support by providing social services. Even though they are not the only Islamists in Egypt, the Muslim Brotherhood is arguably the most widespread Islamic organization with offshoots in other Arabic countries. Officially banned, the Brotherhood's activities were being tolerated insofar as they provided social services that were desperately needed following the state's partial retreat from service providing. In return, the Brotherhood kept a low profile in political affairs, refraining from directly challenging the Mubarak regime. Instead, the Brotherhood followed grassroots politics, gaining support from below by providing social services. Their services ranged from providing health care to matchmaking.

Thanks to this slow but steady support building, the Brotherhood started to participate in formal politics in the late 1980s by forming alliances with the Wafd Party in 1984 and with the Socialist Liberal Party in 1987 (BBC, 2013). Barred from participating in the elections under their own party banner, the Brotherhood contested later elections through independent candidates. In the parliamentary elections of 2005, the Brotherhood candidates relatively prospered, 88 out of 130-150 candidates won in their respective electoral districts, amounting to a 58\% victory rate (Sharp, 2006: 5). Mubarak regime's response to this relative success was harsh, a sweeping crackdown against the Brotherhood was initiated, many members of the organization were either arrested or they were subjected to attacks by pro-government thugs (McCarthy, 2005).

The Brotherhood's electoral success in both Mubarak era and postMubarak elections could be attributed to its organizational and service providing capabilities. However, we should not underestimate the role ideology played in the Brotherhood's appeal. It goes without saying that the Brotherhood was esteemed highly among the pious segments of Egyptian society. Nevertheless, it would be oversimplification to claim that the Brotherhood's popularity solely rested on its ability to enamour religious constituency. While the Brotherhood does not categorically reject neoliberalism (Emerson and Youngs, 2007: 11) its 
cautious attitude towards neoliberalism including free trade (Hamzawy and Brown, 2010: 12) resonated greatly among Egyptians particularly among those who are vulnerable to neoliberal reform agenda. While it is true that Brotherhood's prominent capitalist figures such as Khairat el-Shater and Hassan Malek did little to hide their advocacy towards neoliberalism (Hickel, 2012) and the Brotherhood's political organization Freedom and Justice Party (FJP) actually sustained neoliberal economic policies prevalent during the Mubarak era (Pioppi, 2013: 59), the Egyptian voters were clearly under the impression that the Brotherhood stood against the excesses of neoliberalism (Masoud, 2014: 152). This impression gave the Brotherhood the edge they needed over the others such as the Egyptian Bloc that included old parties such as the socialist alTagaтти.

\subsection{Egyptian Modernization's Effects on Democratization and Egyptian Military}

Egypt's ongoing modernization stemming from economic development through the implementation of neoliberal economic policies including trade liberalization does not have the potential to democratize Egypt beyond few superficial alterations. Richard Youngs contends that most authoritarian regimes in the Middle East have been "gatekeepers to free-trade agreement-linked reforms, using them to enhance their networks of political patrimony" (Youngs, 2008). While Youngs' assessment is region-wide, it can nevertheless be claimed that Egypt is a fitting example for exposing the dynamics through which authoritarian regimes, or regime elites to be more specific manipulate trade liberalization to boost their fortunes.

Trade liberalization in Egypt, starting with the Law 43 of 1974, supplemented by the Law 118 of 1975 (World Bank, 1998: x), and accelerated during the last decade of Mubarak's rule, have not been in the best interests of the majority of Egyptians. Instead, a group of state and business elites ${ }^{6}$ have thrived under a regime of free trade, mostly thanks to their trade with the EU market (Afouxenidis and Kourtelis, 2017: 305). What is meant by trade is the dealings of the energy sector and other export-oriented industries with the EU (ibid.: 304), which comes at the cost of the rest of the businesses as they do not receive the same level of protection those export-oriented industries receive from

6 In a country like Egypt, business elites and state elites are often inextricably entwined, the General Secretariat of the former ruling party of Egypt, the NDP, included many prominent businessmen among its ranks (Abdel-Khalek and Al-Sayyid, 2011: 268). This led Gouda Abdel-Khalek and Mustapha Al-Sayyid to suggest that big business was probably the only social class that maintained support for Hosni Mubarak's authoritarian regime (ibid.: 267). 
the state in order to withstand competition coming from the European markets. A relatable scenario is present in Morocco, export-oriented farms based in fertile lands that are being controlled by a group of "agricultural elites" benefit from EU and national projects while other farms that are mostly located in less fertile lands are left to fend for themselves (ibid.: 303).

Before we move on any further with the idea of elites benefiting - more than any other social class - from neoliberal reforms, we need further elaboration about the role Egyptian elites, particularly military elites play in the Egyptian politics and how elites interact among each other. In this regard, Egyptian military elites deserve special attention. Especially in the past, the military played a significant role in Egyptian politics to such an extent that scholars such as Amos Perlmutter and Anouar Abdel-Malek categorized Egypt as a praetorian state - or a military society if we use a different terminology - (Perlmutter, 1974: 4; AbdelMalek, 1968). Egypt also has been pigeonholed as a praetorian state recently, especially after the 2013 coup d'état, for instance by Robert Springborg, who claimed that Egypt was a "bully praetorian republic" in which a military state building project started for the third time in 2015 as the military is once again attempting to manage the entire system without significant civilian input (Springborg, 2015).

A praetorian state, as simply defined by Perlmutter, is a political system in which the military "tends to intervene and potentially could dominate the political system" [emphasis in original] (Perlmutter, 1969: 383). It is up for debate as to whether Egypt could be considered as a state that is completely dominated by the military ${ }^{7}$, although the military has fulfilled a major role in Egyptian politics ever since the inception of the republic. Instead of depicting Egypt as a state in which military asserts a complete dominance, Steven Cook (2007: 63) portrays Egypt as a state in which military or the military officers kept a low profile - in comparison to their Algerian and Turkish counterparts - yet Egypt's senior command still exerted a significant degree of influence over the Egyptian political system. In Cook's words, the Egyptian military was able to "rule without having to govern" (ibid.: 2).

It is true that the Egyptian military has always been an influential player in the Egyptian politics. Still, even if we consider this influence as the evidence

7 In fact, Perlmutter himself distinguished between two types of praetorian states: 1) Arbitrator type, 2) Ruler type. In arbitrator type of praetorian states, the military imposes a time limit on its rule and hands over the government back to civilians when the time comes. The military's influence over the regime lingers however and the military may assume control once again if they deem it necessary. On the contrary, in a ruler type praetorian state, the military's power is maximized, and it maintains direct control over the state (Perlmutter, 1974: 6-9). 
of praetorianism, it is not possible to claim that the Egyptian politics throughout the entire republic period is marked by military domination. In a way, the Egyptian Republic has been a praetorian state right from the beginning, the Republic came into being following a successful coup d'état by the Free Officers. All the presidents before Mohamed Morsi hailed from the ranks of military, even though all of them had shed their uniforms before they assumed the office of president. However, the degree of praetorianism declined in Egypt, especially during the later period of the Mubarak's rule, even though praetorianism or military's influence never really vanished, and it played a decisive role both in Mubarak's downfall and the subsequent events.

Praetorianism's decline over the years partly stems from the relationship between praetorianism and modernization. As stated by Perlmutter, there is an inherent connection between these two concepts, "praetorianism often appears in states which are in the early stages of modernization and industrialization" (Perlmutter, 1974: 5). By the same token, we should expect a decrease in the level of praetorianism as a state goes through phases of modernization.

Egypt's ongoing modernization accounts for the decline of praetorianism in Egypt. Indeed, Egypt partially lost its praetorian character by going through an extensive period of modernization. Praetorianism was strong in Egypt, especially in the early years of Nasser's reign, partly because the military faced no real opposition, not even from the Muslim Brotherhood (Kurtzer and Svenstrup, 2012: 43). However, Egypt's "entrenched military" saw a decrease in their capability to affect the Egyptian politics towards the end of the Nasser period, as Nasser, under the pretext of calling the military to account for the defeat against Israel in 1967, purged not just the popular Field Marshall Abdel Hakim Amer, but also the remaining military leadership from the 1952 coup d'état, which naturally enhanced Nasser's power vis-à-vis the military establishment, turning the latter into an organization more along the lines of professionalism (ibid.). As the years proceeded, military further distanced themselves from daily politics, which ensured that Sadat faced little challenge from the military, and in return, Sadat allowed the military to increase its privileged status in Egypt (ibid.: 43-44). In other words, in exchange for political docility, military's privileged status in Egypt continued, up until the final years of Mubarak in power.

As modernization progressed, so did the influence of civilians over decision making. Especially in the beginning of the 2000s, a new clique of civilians emerged, under the leadership of Gamal Mubarak, who had just returned from London working as an investment banker. This new group, the so-called new guard that consists of business elites replaced the old guard (Roll, 2010), who had been influential over decision making process in Egypt up until their ousting. The old guard consisted of figures such as Zakaria Azmi, a former army 
officer, who was Mubarak's presidential chief staff for 22 years until Mubarak's deposal in 2011 (Al Jazeera, 2011), and Safwat El-Sherif.

Increasing civilian input in Egyptian politics never reached to a point of complete dismantlement of praetorianism. The military refrained from meddling in the affairs of the Mubarak regime, especially regarding daily politics, as long as their vested interests such as business enterprises and military aid flowing from the US remained untouched. Steven Cook claims that the military establishment's interests were never in danger of Sadat regime's infitah, on the contrary, the military establishment reaped the benefits of it, including "foreign direct investment and the potential rent streams it produced" (Cook, 2007: 80). Not everyone agrees with Cook's assessment however, for instance, according to David Kirkpatrick's report, some economists believed that because of their vested interests, the military stood against the transition from Nasser regime's state dominated economy to Mubarak regime's free market- oriented economy (Kirkpatrick, 2011).

The Egyptian military's low-key involvement in Egyptian politics came to an abrupt end and praetorianism made a comeback when the civilian rule, which leaned heavily on a neoliberal agenda, proved to be unsustainable. In response, the military jettisoned Mubarak by refusing to open fire on the masses of protesters. When Morsi's short and ill-fated presidency again turned out to be unsustainable, the military intervened once again, this time even more directly, and removed him from power.

In sum, the Egyptian military's fluctuating influence over the Egyptian politics does not completely account for the neoliberal transformation, after all, trade liberalization, or neoliberalism in general was the most intense when the civilians within the Mubarak regime maximized their influence regarding policy making, Also, as has been mentioned, neoliberal economic reforms - which naturally includes trade liberalization - had the potential to curtail military elites' economic interests ${ }^{8}$, thus, instead of military officers, we should expect civilian elites to be the main instigators of neoliberal reforms, and this was exactly the case, following Gamal Mubarak's ascension into prominence.

\subsection{Trade Liberalization and Democratization in Egypt}

At its current state, free trade policies in Egypt do not have the potential for being beneficial for Egyptians, save for a bunch of crony capitalists, because they were negotiated by a small clique of politicians that happened to have close

8 Similarly, Henry Bienen asserts that in the African countries, opposition to trade liberalization resides within the military bureaucracies and instead import substitution is the favoured model (Bienen, 1990: 714-715). 
ties with the business elites and in some cases, those politicians were recruited from the ranks of businessmen. To put it in another way, free trade agreements that were negotiated, agreed and implemented in the past in Egypt are problematic regarding legitimacy. A free trade agreement may lack legitimacy which in return could affect the agreement's impact on peace - if the population affected by the agreement feels that elites that are negotiating on their behalf actually promote their own narrow business interests (Oli Brown, 2013: 15).

In the past, the European Parliamentary Labour Party within the European Parliament raised its voice against a free trade agreement, which the EU planned to strike with Colombia because of the way the Colombian government treated the trade unions within the country (ibid.). No such concerns were ever taken into consideration when the EU negotiated and eventually signed an association agreement with Egypt despite the fact that both the Atef Ebeid government that conducted the negotiations and its successor the Ahmed Nazif government that further liberalized trade in Egypt (Dabrowski, 2011) had questionable democratic legitimacies, to put it mildly. Especially, the Nazif government was known for its fervent support for neoliberal reforms in Egypt. However, the real mastermind behind the Nazif government's neoliberalist agenda including trade liberalization was no other person than Gamal Mubarak himself. Gamal orchestrated the appointments of the Nazif government, many ministers, including the prime minister Nazif, were actually his proteges (Dunne, 2006: 5). By virtue of his kinship, Gamal was able to purge the "old guard" of the NDP (Lesch, 2011: 39) and from that moment, he and his disciples were free to steer the course of Egypt towards a future defined by neoliberalism. For instance, Rachid Mohamed Rachid, a wealthy businessman and a political ally of Gamal (Mada Masr, 2016), was tasked with liberalizing industry and international trade (Lesch, 2011: 39). Rachid fled the country on February 2011 after the Mubarak regime had fallen and he was sentenced to prison in absentia on charges of corruption and embezzlement (Mada Masr, 2016).

To sum up, trade openness in Egypt was never designed in a fashion that would be conducive to economic development and welfare for the entire Egyptian society. Instead, trade liberalization was constituted in such a way that it would only be lucrative for a small segment of society. Apart from the elites that designed such policies, free trade policies or economic liberalization policies in general were never meant to be beneficial for the majority of Egyptians. This should not come as a surprise as the Mubarak regime never entirely relied on the support of the masses for the maintenance of the authoritarian polity. While the Mubarak regime did not fully liberalize the Egyptian economy - thus the state maintained its service providing function to a certain extent - it nevertheless continued Sadat regime's policy of depending on rents such as the revenue coming from the Suez Canal or foreign aid flowing from the US. The regime 
reckoned that it did not need the support of the ordinary Egyptians like the Nasser regime did, hence the empowerment of the lower classes and the middle classes was an afterthought at best. Therefore, lower class and particularly middle class Egyptians did not fully develop the means to pressure for a more pluralist political system. Overthrowal of the corrupt regime of Mubarak was perhaps inevitable since Mubarak could not have sustained his authoritarian regime by depending solely on elite support and security services. However, establishing a durable democratic system has not been possible for long-impoverished Egyptians, not surprisingly, makeshift democracy in Egypt crumbled in a short period of time and authoritarianism re-emerged, perhaps this time in an even less inclusionary form.

\section{Conclusion}

As can be inferred from the conflicting views in the literature, in general, the relationship between free trade and democratization is not inherently ominous. However, the region of Middle East stands in stark contrast to this conclusion, following nearly five decades of free trade policies, coupled with other neoliberal measures, has not led to a democratic breakthrough in the Middle East. Essentialist explanations such as Arab or Muslim exceptionalism have been advanced in order to explain the democracy deficit in the Middle East. However, there is something more sinister at play in the Middle East, something wrong with the way the free trade policies in the region are designed and implemented. In its current state, free trade policies do have the capacity to provide economic growth - measured in terms of GDP - to the Middle Eastern countries. Nevertheless, economic growth in terms of GDP alone means little for democratization, a country's prospects for democratization does not increase if the economic growth comes at the expense of a significant majority of a country's population. Elites being in the driving seat of trade liberalization means that said policies are designed and implemented in a way that would cater to nothing but narrow elite interests.

Egypt is quintessentially Middle Eastern in the sense that free trade policies and economic liberalization in general has not led to a genuine democratization but instead they further widened the gap between the regime elites and the rest of the population and this in return has important ramifications regarding nascent democratization in Egypt. It is no wonder that democratization in Egypt has always remained embryonic as the middle class in the country was and is devoid of autonomous capacity to pressure the elites to concede to democratization and the neoliberal economic policies including trade liberalization has certainly not rectified this situation. 
That is why democratization has been at the mercy of a small group of elites who have been ingenious to bend it to their own will. Especially during the Mubarak era, a small group of politicians, often hailing from the ranks of the business world, initiated trade liberalization, in a fashion that would mostly serve their own interests. Those politicians were known for their affinity towards Gamal Mubarak, the second son of country's long-time authoritarian leader Hosni Mubarak, personally groomed by him to become Egypt's next ruler. Because accountability and transparency under a democratic regime meant that their interests would be threatened, these elites did not to concede to meaningful democracy, so the regime continued to maintain an iron grip over the Egyptian society, despite paying lip service to democratization through introducing meaningless changes such as multi-candidate presidential elections. This only worked to a certain degree however, the regime simply signed its own death warrant when it pursued policies that alienated a significant portion of Egyptians. Yet in the grand scheme of things, this does not mean much for democratization in Egypt, the collapse of an authoritarian regime is not always followed by democratization, as the example of Egypt has vividly demonstrated.

\section{References}

Abdel-Khalek, Gouda and Mustapha K. Al Sayyid (2011), "Egypt: Development, Liberalization and the Persistence of Autocracy", Elbadawi, Ibrahim and Samir Makdisi, (Ed.), Democracy in the Arab World: Explaining the Deficit (Abingdon and New York: Routledge): 256-281.

Abdel-Malek, Anouar (1968), Egypt: Military Society: The Army Regime, the Left, and Social Change under Nasser (Berkeley, Los Angeles and London: University of California Press).

Acemoğlu, Daron and James A. Robinson (2006), Economic Origins of Dictatorship and Democracy (New York: Cambridge University Press).

Afouxenidis, Alex and Christos Kourtelis (2005), "Reflections on Neoliberal Policy: A Critical Insight into Recent Development Practices in Egypt and Morocco", Open Journal of Political Science, 7 (2): 291-310.

Alcala, Francisco and Antonio Ciccone (2004), "Trade and Productivity", The Quarterly Journal of Economics, 2 (1): 613-646.

Al Jazeera (2011), "Mubarak's Former Chief of Staff Arrested", https://www.aljazeera.com/ news/middleeast/2011/04/20114720540306784.html (25.02.2019).

American Chamber of Commerce in Egypt (2018), https://www.amcham.org.eg/informationresources/trade-resources/egypt-us-relations/trade-investment-relations-profile (25.10.2018).

Barro, Robert J. (1999), "Determinants of Democracy”, Journal of Political Economy, 107 (S6): 158183. 
Barro, Robert J. (2015), “Convergence and Modernisation”, The Economic Journal, 125 (585): 911942.

BBC (2013), "Profile: Egypt's Muslim Brotherhood”, https://www.bbc.com/news/world-middle-east12313405 (15.02.2019)

Beinin, Joel. (2007), "The Militancy of Mahalla al-Kubra", Middle East Report Online https://merip.org/2007/09/the-militancy-of-mahalla-al-kubra/ (14.02.2019).

Beinin, Joel (2012), "Egyptian Workers and January 25 $5^{\text {th. }}$ A Social Movement in Historical Context”, Social Research, 79 (2): 323-348.

Bienen, Henry (1990), "The Politics of Trade Liberalization in Africa”, Economic Development and Cultural Change, 38 (4): 713-732.

Brown, Oli (2013), "The Impact of EU Trade Agreements on Conflict and Peace", Civil Society Dialogue Network Discussion Paper No. 2, http://eplo.org/wpcontent/uploads/2017/03/EPLO_CSDN_Discussion-Paper_Trade-Agreements.pdf (05.11.2018).

Brownlee, Jason (2003), "The Decline of Political Pluralism in Mubarak's Egypt”, Diamond, Larry, Marc F. Plattner and Daniel Brumberg (Ed.), Islam and Democracy in the Middle East (Baltimore and London: The Johns Hopkins University Press): 48-57.

Brownlee, Jason (2012), Democracy Prevention: The Politics of the U.S.-Egyptian Alliance (New York: Cambridge University Press).

Carlsson, Fredrik and Susanna Lundström (2002), "Economic Freedom and Growth: Decomposing the Effects", Public Choice, 112 (3-4): 335-344.

Central Intelligence Agency (2017), https://www.cia.gov/library/publications/the-worldfactbook/rankorder/2172rank.html (17.10.2018).

Cevheri, Ertuğrul (2018), “Avrupa Birliği'nin Akdeniz'deki Demokrasi Teşviki Politikaları: Mısır Örneği”, Unpublished PhD Thesis, Ankara University, Turkey.

Chick, Kristen (2017), "Egypt's Civil Society is on Life Support”, https://foreignpolicy.com/ 2017/12/13/egypts-civil-society-is-on-life-support/ (30.10.2018).

Clinton, Bill (1996), Between Hope and History: Meeting America's Challenge for the $21^{\text {st }}$ Century (New York: Random House)

Collier, David (1979), "Overview of the Bureaucratic-Authoritarian Mode", Collier, David (Ed.), The New Authoritarianism in Latin America (Princeton: Princeton University Press): 19-32.

Cook, Steven A. (2007), Ruling but not Governing: The Military and Political Development in Egypt, Algeria and Turkey (Baltimore: Johns Hopkins University Press).

Cook, Steven A. (2013), The Struggle for Egypt: From Nasser to Tahrir Square (New York: Oxford University Press).

Dabrowski, Marek (2011), “Egypt: Political Transition vs. Economic Challenges?”, CASE Network Ebriefs No. 07, https://ideas.repec.org/p/sec/ebrief/1107.html (06.11.2018).

Daily News Egypt (2008), "The Mismanagement of the Bread Crisis”, https://dailynewsegypt.com/ 2008/03/18/the-mismanagement-of-the-bread-crisis/ (02.08.2017).

De Ville, Ferdi and Vicky Reynaert (2010), "The Euro-Mediterranean Free Trade Area: An Evaluation on the Eve of the (Missed) Deadline”, L'Europe en Formation, 356 (2): 193-206.

Dunne, Michele (2006), “Evaluating Egyptian Reform”, Carnegie Papers Number 66, https://carnegieendowment.org/2006/01/24/evaluating-egyptian-reform-pub-17940 (22.05.2018). 
Dunne, Michele (2007), "Time to Pursue Democracy in Egypt", Carnegie Endowment for International Peace Policy Outlook, https://carnegieendowment.org/files/Dunne_Egypt_FINAL2.pdf (23.10.2018).

Emerson, Michael and Richard Youngs (2007), "Political Islam and the European Neighbourhood Policy", Emerson, Michael and Richard Youngs, (Ed.), Political Islam and European Foreign Policy: Perspectives from Muslim Democrats of the Mediterranean (Brussels: Centre for European Policy Studies): 1-12.

European Commission (2018a), http://ec.europa.eu/trade/policy/countries-and-regions/countries/ egypt/ (09.10.2018).

European Commission (2018b), http://europa.eu/rapid/press-release_MEMO-95-2_en.htm (20.10.2018).

Export.gov (2018), "Egypt - Market Overview", (2018), https://www.export.gov/article?id=EgyptMarket-Overview (23.10.2018).

Freedom House (2018), https://freedomhouse.org/report/freedom-world/2018/russia (17.10.2018).

Gad, Emad (2003), "Egyptian-European Relations: From Conflict to Cooperation”, The Review of International Affairs, 3 (2): 173-189.

Grossman, Perry (2002), "The Effects of Free Trade on Development, Democracy, and Environmental Protection", Sociological Inquiry, 72 (1): 131-150.

Hamzawy, Amr and Nathan Brown (2010), "The Egyptian Muslim Brotherhood: Islamist Participation in a Closing Political Environment", Carnegie Papers Number 19, https://carnegieendowment.org/files/muslim_bros_participation.pdf (18.02.2019).

Hassanein, Haisam (2017), "Does Egypt need an FTA with the United States?", The Washington Institute Policywatch 2789, https://www.washingtoninstitute.org/policy-analysis/view/doesegypt-need-an-fta-with-the-united-states (22.10.2018).

Heredia, Carlos (1994), "NAFTA and Democratization in Mexico", Journal of International Affairs, 48 (1): 13-38.

Herrold, Catherine and Mona Atia (2016), "Competing Rather than Collaborating: Egyptian Nongovernmental Organizations in Turbulence", Nonprofit Policy Forum, 7 (3): 389-407.

Hickel, Jason (2012), "Neoliberal Egypt: The Hijacked Revolution”, https://www.aljazeera.com/ indepth/opinion/2012/03/201232784226830522.html (19.02.2019).

Hinnebusch, Raymond (1988), Egyptian Politics Under Sadat: The Post-Populist Development of an Authoritarian-Modernizing State (Updated Edition) (Boulder: Lynne Rienner Publishers).

Hinnebusch, Raymond (2000), "Liberalization without Democratization in "Post-Populist Authoritarian States": Evidence from Syria and Egypt", Butenschon, Nils A., Uri Davis and Manuel Hassassian (Ed.), Citizenship and the State in the Middle East: Approaches and Applications (New York: Syracuse University Press): 123-145.

Kandil, Hazem (2012), "Why did the Egyptian Middle Class March to Tahrir Square?", Mediterranean Politics, 17 (2): 197-215.

King, Stephen J. (2003), Liberalization against Democracy: The Local Politics of Economic Reform in Tunisia (Bloomington: Indiana University Press).

Kirkpatrick, David D. (2011), "Egyptians Say Military Discourages an Open Economy", https://www.nytimes.com/2011/02/18/world/middleeast/18military.html (04.03.2019).

Kurtzer, Daniel and Mary Svenstrup (2012), "Egypt's Entrenched Military”, The National Interest, 121: 40-50. 
Lesch, Ann M. (2011), “Egypt's Spring: Causes of the Revolution”, Middle East Policy, XVIII (3): 3548.

Li, Quan and Rafael Reuveny (2003), "Economic Globalization and Democracy: An Empirical Analysis", British Journal of Political Science, 33 (1): 29-54.

Lipset, Seymour Martin (1959), "Some Social Requisites of Democracy: Economic Development and Political Legitimacy", The American Political Science Review, 53 (1): 69-105.

Liu, Xuepeng and Emanuel Ornelas (2014), "Free Trade Agreements and the Consolidation of Democracy", American Economic Journal: Macroeconomics, 6 (2): 29-70.

Lopez-Cordova J. Ernesto and Christopher M. Meissner (2008), "The Impact of International Trade on Democracy: A Long-run Perspective”, World Politics, 60 (4): 539-575.

Lynch, Marc (2011), "The Big Think Behind the Arab Spring", https://foreignpolicy.com/ 2011/11/28/the-big-think-behind-the-arab-spring/ (15.02.2019).

Mada Masr (2016) "Reconciliation Deal with Mubarak-era Fugitive Trade Minister Rachid", https://madamasr.com/en/2016/11/29/news/u/reconciliation-deal-with-mubarak-erafugitive-trade-minister-rachid/ (25.11.2018).

Marquis, Christopher (2001), "Bush Says He'll Press Effort For Hemisphere Trade Pact", https://www.nytimes.com/2001/04/18/world/bush-says-he-II-press-effort-for-hemispheretrade-pact.html (15.10.2018).

Masoud, Tarek (2014), Counting Islam: Religion, Class, and Elections in Egypt (New York: Cambridge University Press).

McCarthy, Rory (2005), "Muslim Brotherhood Finds Voice at the Ballot Box Despite Mubarak Crackdown", https://www.theguardian.com/world/2005/nov/24/rorymccarthy.mainsection (18.02.2019)

Mikhail, Amira (2014), "The Obliteration of Civil Society in Egypt", https://www.opendemocracy.net/ north-africa-west-asia/amira-mikhail/obliteration-of-civil-society-in-egypt (30.10.2018).

Milner, Helen V. and Keiko Kubota (2003), "Why the Move to Free Trade? Democracy and Trade Policy in the Developing Countries", International Organization, 59 (1): 107-143.

Mishrif, Ashraf. (2010), Investing in the Middle East: The Political Economy of European Direct Investment in Egypt (London and New York: I. B. Tauris Publishers).

Nasser, Gamal Abdel (1955), "The Egyptian Revolution", https://www.foreignaffairs.com/ articles/egypt/1955-01-01/egyptian-revolution (27.10.2018).

Nation Master (2005), https://www.nationmaster.com/country-info/stats/Health/Physicians/Per1\%2C000-people\# (18.10.2018).

O'Donnell, Guillermo (1973), Modernization and Bureaucratic-Authoritarianism: Studies in South American Politics (Berkeley: University of California, Institute for International Studies).

Perlmutter, Amos (1969), "The Praetorian State and the Praetorian Army: Toward a Taxonomy of Civil-Military Relations in Developing Polities", Comparative Politics, 1 (3): 382-404.

Perlmutter, Amos (1974), Egypt the Praetorian State (New Brunswick, NJ: Transaction Books).

Pioppi, Daniela (2013), "Playing with Fire. The Muslim Brotherhood and the Egyptian Leviathan", The International Spectator, 48 (4): 51-68.

Reuters (2014), "Egypt Political Parties Concerned over New Parliamentary Election Law", https://www.reuters.com/article/us-egypt-election/egypt-political-parties-concerned-overnew-parliamentary-election-law-idUSKBNOEH16L20140606 (01.11.2018). 
Reynaert, Vicky (2011), "Preoccupied with the Market: The EU as a Promoter of 'Shallow' Democracy in the Mediterranean", European Foreign Affairs Review, 16 (5): 623-637.

Rigobon, Roberto and Dani Rodrik (2005), "Rule of Law, Democracy, Openness and Income: Estimating the Interrelationships", Economics of Transition, 13 (3): 533-564.

Rodriguez, Francisco. and Dani Rodrik (2001), “Trade Policy and Economic Growth: A Skeptic's Guide to the Cross-National Evidence", NBER Macroeconomics Annual 2000, 15: 261-338.

Roll, Stephan (2010), "Gamal Mubarak and the Discord in Egypt's Ruling Elite", https://carnegieendowment.org/sada/41490 (25.02.2019).

Rosen, Ellen Israel (2002), Making Sweatshops: The Globalization of the U.S. Apparel Industry (Berkeley, Los Angeles and London: University of California Press).

Schweller, Randall (2000), “US Democracy Promotion: Realist Reflections”, Cox, Michael, G. John Ikenberry and Takashi Inoguchi (Ed.), American Democracy Promotion: Impulses, Strategies and Impacts (New York and Oxford: Oxford University Press): 41-62.

Sharp, Jeremy M. (2006), "Egypt: 2005 Presidential and Parliamentary Elections", CRS Report for Congress,

https://digital.library.unt.edu/ark:/67531/metacrs10216/m1/1/high_res_d/RS22274_2006J an15.pdf (18.02.2019).

Sharp, Jeremy M. (2011), "Egypt: Background and U.S. Relations", CRS Report for Congress, http://www.voltairenet.org/IMG/pdf/Egypt_Background_and_U-S-_Relations.pdf (22.10.2018).

Springborg, Robert (2015), "Arab Armed Forces: State Makers or State Breakers", https://www.mei.edu/publications/arab-armed-forces-state-makers-or-state-breakers (21.02.2019).

Tamkin, Emily (2017), "In Policy Reversal, US Withholds Aid to Egypt”, https://foreignpolicy.com/ 2017/08/23/in-policy-reversal-u-s-withholds-aid-to-egypt-trump-sisi/ (22.10.2018).

United Nations (2003), Annual Review of Developments in Globalization and Regional Integration in the Countries of the ESCWA Region, 2002, (New York).

Waterbury, John (1994), "Democracy without Democrats? The Potential for Political Liberalization in the Middle East", Salame, Ghassan, (Ed.), Democracy without Democrats? The Renewal of Politics in the Muslim World (London and New York: I. B. Tauris Publishers): 23-47.

World Bank (1998), Egypt in the Global Economy: Strategic Choices for Savings, Investments, and Long-Term Growth (Washington DC).

World Bank (2017), https://data.worldbank.org/indicator/NY.GDP.PCAP.CD (17.10.2018).

Youngs, Richard (2008), "Linking Free Trade and Democracy: The European Union's Experience in the Middle East", https://carnegieendowment.org/sada/21532 (01.11.2018). 